\title{
Soil Water Studies in Oxisols and Ultisols of Puerto Rico: I. Water Movement ${ }^{1}$
}

\author{
James $M$. Wolf and Matthew Drosdoff ${ }^{2}$
}

\begin{abstract}
Soil water experiments were conducted to determine the water supplying characteristics of two clayey Ultisols, a clayey Oxisol, and a sandy Oxisol. Water infiltration into all soils was very rapid, reaching 9 $\mathrm{cm} / \mathrm{hr}$ after $1 \mathrm{hr}$ of continuous flooding. The strong structural stability of the clay soils permitted infiltration rates in excess of that for the sandy soil.

Lateral water movement, downslope, was a significant factor in observed high rates of water infiltration and may partially account for downslope movement of nitrates.

Values of soil water tension after 2 to 3 days of free drainage did not exceed 20 to $80 \mathrm{~cm}$ of water (roughly $1 / 50$ to $1 / 12$ bar). Field capacity was established to be $1 / 15$ bar for the sandy Oxisol and $1 / 20$ bar for the clayey Oxisol and Ultisols.

Two avenues of soil water movement were postulated: Capillary pores (between soil particles) and non-capillary pores (between soil aggregates). Because of water movement in non-capillary pores, flow characteristics of the clay soils resembled that of the sand. In terms of soil water release characteristics, the clays and the sand were similar.
\end{abstract}

\section{INTRODUCTION}

In vast areas of the Humid Tropics soils are strongly leached and very acidic. Soil acidity is commonly associated with Al toxicity, and these factors create a hostile soil environment which chemically limits the

${ }^{1}$ Submitted to Editorial Board April 25, 1975.

${ }^{2}$ Formerly Lecturer, Department of Agricultural Engineering, now with CIDIAT, Mérida, Venezuela, and Professor of Soil Science, Department of Agronomy, respectively, Cornell University, Ithaca, N.Y., in cooperation with the Agricultural Experiment Station of the University of Peurto Rico and with the support of the U.S. Agency for International Development under Research Contract csd 2490. The authors are indebted to several people for assistance during the course of the work. Dr. Richard Fox was singularly helpful in providing logistic support. Gaston Amedee assisted greatly in both the laboratory and field. Drs. Levine and Bouldin willingly gave their time in reviewing this material. Many other people at Rio Piedras, Corozal, and the other sites gave assistance when needed. Special thanks are due Dr. Miguel A. Lugo-López for his assistance in preparing the manuscript for publication. Lastly, the senior author acknowledges the continued support by the Agricultural Engineering Department, Cornell University, which enabled him to undertake this work. 
depth of rooting of crops such as corn and sorghum. At present, liming soil to a depth of more than the surface foot is not practical. Crops which are sensitive to soil acidity are effectively limited to the depth of the soil profile to which lime may be incorporated. This severely limits the amount of soil water and nutrients which a crop can utilize.

In the case of water, rooting limitations increase the likelihood of yield decreases when rainfall distribution is anything short of ideal. In order to assess the potential for successful cropping, information regarding climatic factors must be superimposed upon those soil physical properties which affect the water supplying characteristics of the soils. The climatic information required should include rainfall distribution and potential evapotranspiration.

The purpose of the soil water experiments conducted in Puerto Rico during the summer of 1971 was to determine the water supplying characteristics of four soils on which fertility experimentation was in progress or planned. A previous survey of moisture relationships of over 100 Puerto Rico soils has been made by Lugo-López (1).

The soil water information obtained from the experiments herein reported should be useful in characterizing the soils for purposes of subsequent experimentation by future workers in the area. An evaluation of the soil physical characteristics together with climatic data may be useful to predict their combined effect upon crop yield and permit conclusions relative to the likelihood of successful cropping.

This is the first of a series of four papers on soil water studies conducted on Oxisols and Utisols of Puerto Rico. Forthcoming papers will deal with water retention and availability, capillary conductivity, and the comparison of several possible techniques for obtaining this information for these types of soils.

\section{MATERIALS AND METHODS}

SOILS

\section{Humatas Series}

Location: Corozal Substation

Classification: Typic Tropohumults, clayey, kaolinitic, isohyperthermic

Texture: Clay loam to clay

Slopes: Top of hill; 0 to $14 \%$

Vegetation: Cultivated; corn and grass

\section{Catalina Series}

Location: Margaro's farm near Barranquitas

Classification: Typic Haplorthox, clayey, oxidic, isohyperthermic 
Texture: Clay

Slopes: 3 to $8 \%$

Vegetation: Cultivated; starchy food crops

\section{Torres Series}

Location: Dr. Hilda Soltero's farm near Cidra

Classification: Orthoxic Palehumults, clayey, kaolinitic, isohyperthermic

Texture: Clay

Slopes: 1 to $3 \%$

Vegetation: Cultivated; pasture

\section{Bayamón Series}

Location: Fundador farm east of Manatí

Classification: Typic Haplorthox, clayey, oxidic, isohyperthermic

Texture: Loamy sand

Slopes: 0 to $2 \%$

Vegetation: Cultivated; pineapples

To characterize the soils in the instrumented areas two pits were dug to a depth of $150 \mathrm{~cm}$. Location of the pits close to the instrumented areas facilitated study of lateral water movement. Soil samples were taken at $15-\mathrm{cm}$ intervals to a depth of $150 \mathrm{~cm}$.

Undisturbed soil core samples, two per depth per pit, were taken at the 30-, 60-, 90-, and 120-cm depths. These samples, $7.62 \mathrm{~cm}$ in diameter by $7.62 \mathrm{~cm}$ long, were obtained by driving aluminum core rings into the ground with a modified Uhland sampler. Cores were removed from the ground with pick and shovel. They were trimmed with a knife, placed in pint-size ice cream containers, and stored in a refrigerator. Loss of water while in the refrigerator resulted in some soil shrinkage from the walls of the rings on some samples high in clay. Cores were later sealed in plastic bags to reduce water loss. Upon saturation, the soils expanded to fill the rings.

Undisturbed core samples were used to determine soil bulk density. Bulk densities were calculated from the dry weight of soil in the undisturbed cores after making soil water release measurements.

Cores, still in the metal rings, were placed in Tempe Cells. They were initially wetted with $5 \times 10^{-4} \mathrm{M} \mathrm{CaCl}_{2}$ at slight tensions and finally saturated with the solution at slight positive pressure. To ensure saturation of the entire core sample, the wetting process took more than $24 \mathrm{hr}$. Pressures between $20 \mathrm{~cm}$ of water and ${ }^{{ }^{3}} 4$ atmosphere were applied and the effluent volume was collected beneath each cell at each pressure step. The time required to run all pressure steps was approximately 1 month. 
Since there were 80 samples to be run, a second method was employed to speed the determinations. A single piece of cheesecloth was placed at the bottom of each core and attached to the metal ring using a rubber band. These cores were wetted from the bottom in low washing dishes using the same solution of calcium chloride. Six samples were then placed in a pressure plate extractor and pressure was applied at similar steps. After cores reached equilibrium with the pressure plate, they were removed and weighed. Before the cores were replaced on the pressure plate, the plate was wetted to ensure good contact between core and plate.

After the pressure step at ${ }^{3} 4$ atmosphere, cores were weighed, then oven dried and reweighed. Soil water contents were calculated as percent by weight and then converted to volumetric water contents which were graphed versus tension.

Conversion to volumetric water content was made through the relationship: $P_{u}=p \cdot P_{w}$

where: $P_{v}=$ Volumetric water content

$P_{w}=$ Water content on a dry weight basis

$p=$ Soil bulk density

Water content and tension determinations for $1_{3,3}, 2_{3}, 1,5$, and 15 atmospheres were also made on a pressure plate apparatus using: disturbed soil samples and standard techniques.

Tensiometers have been used widely as a tool in agronomic and soil water investigations $(2,3,4,5,7)$. The tensiometers used in this study were easily and cheaply constructed. Information on tensiometer construction and calibration is given by Richards (5).

The tensiometer cups at the $7.5-\mathrm{cm}$ depth were placed in a horizontal position (L-shaped) while those at greater depths were vertical. Tensiometer readings were recorded as soil water tension values at the appropriate depths.

Tensiometers were installed at depths of $7.5,30,60,90$, and $120 \mathrm{~cm}$. In the Catalina and Bayamón soils one tensiometer was installed at each depth for a total of five tensiometers per plot. In Humatas and Torres two tensiometers were installed at each depth for a total of ten per plot. Where tensiometers were duplicated, readings were averaged for that depth to obtain values of soil water tensions. In general, there was good agreement between duplicated tensiometers.

A small auger with a diameter greater than the outside diameter of the PVC tubing was used to bore the holes for the tensiometers. After the instrument was inserted into the ground, the soil was packed tightly around the ceramic cup and the PVC wall of the tensiometer. The importance of a proper back-fill and tamping operation cannot be overemphasized. 
After installation in the soil, the tensiometers were filled with boiled tap water. Before connecting the instruments to the manometers, the tensiometers were tapped to loose bubbles from the sides of the PVC tubing. The L-shaped tensiometers were probed to loose bubbles entrapped horizontally.

Experimental areas were square plots, $3.2 \times 3.2 \mathrm{~m}$, an area slightly larger than 1/1000 ha. Prior to irrigation, boards were installed around the plots to a depth of $15 \mathrm{~cm}$ and sides were covered with plastic to permit uniform flooding.

Plots were irrigated by flooding with water, then covered with 6-mil polyethylene plastic. The amount of water applied was determined

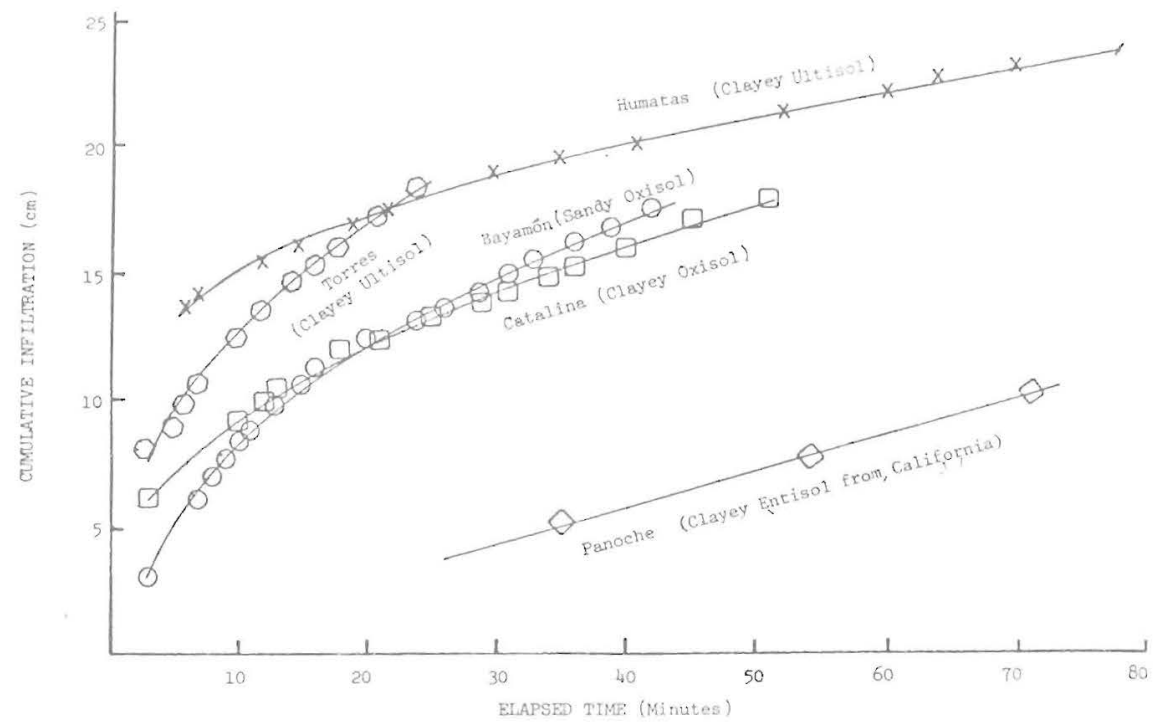

FIG. 1.-Cumulative infiltration versus time for four Puerto Rico soils and for an Entisol from California.

directly in Torres and Catalina soils where the water was applied from a 500-gal tank or from 55-gal drums. In the case of Humatas and Bayamón soils, a stop-watch and a 55-gal drum were used to determine pump discharge rates.

\section{RESULTS AND DISCUSSION}

\section{WATER INFILTRATION}

A graph of cumulative infiltration versus time for the four soils is shown in figure 1 . The amount of water infiltrated per unit time on Humatas and Torres, the Ultisols, exceeded that for Bayamón or Catalina, the Oxisols. This is due in part to the greater lateral water movement in Humatas and Torres. Although Catalina is a clay and 
Bayamón is a loamy sand, the amount of water infiltrated and the intake rates on the two soils were similar. It would be unusual to find soils in temperate regions of widely varied textures exhibiting similar intake rates, other factors being equal.

Shown on the graph for comparative purposes is the infiltration versus time curve for Panoche clay loam (Typic Torriorthents). This is a deep, well-drained, California soil high in montmorillonitic clays (8). Although the amounts of water infiltrated are much greater for the Puerto Rico soils than for the California soil, infiltration rates at $40 \mathrm{~min}$ are similar.

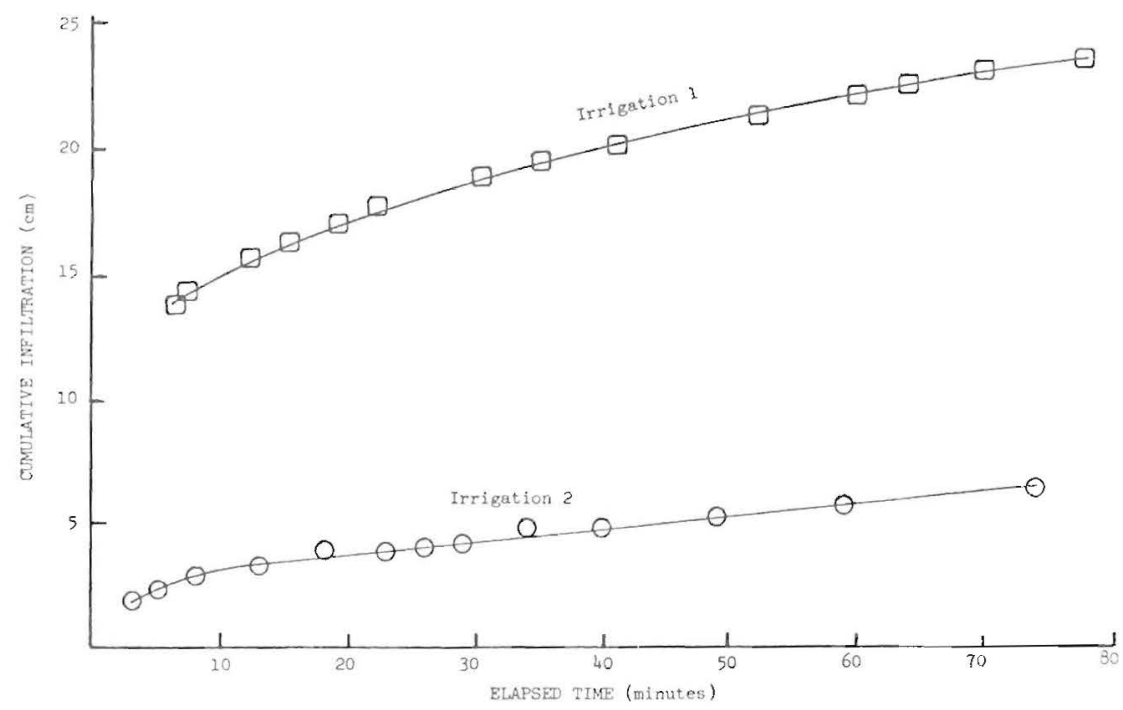

FIG. 2.-Cumulative infiltration versus time for Humatas clay.

Figure 2 shows cumulative infiltration versus time for two irrigations on the same plot on Humatas clay. Before the second irrigation, polyethylene plastic was placed around the plot to a depth of $60 \mathrm{~cm}$ to restrict lateral movement. Soil water contents (percent by dry weight) were greater prior to the second irrigation. These are presented in the following tabulation:

\begin{tabular}{ccc} 
Depth & \multicolumn{2}{c}{ Irrigation } \\
Cm & 1 & 2 \\
7.5 & 43 & 50 \\
30 & 44 & 50 \\
60 & 34 & 38 \\
90 & 36 & 35 \\
120 & 38 & 37
\end{tabular}

The marked reduction in rate of initial water infiltration in irrigation 2 was due to: 1) Higher initial soil water content; 2) reduction in lateral water movement; 3) compaction caused by foot traffic. 
At extended periods of time infiltration rates were similar. Infiltration rate at that time reflects the steady state rate of water transport through the soil when the majority of soil pores are filled and conducting water.

\section{LATERAL MOVEMENT OF WATER}

A comparative qualitative assessment of lateral water movement was made by observing the entry of water into the pits surrounding the irrigated areas. Lateral water movement was greatest in the Humatas soil, where water movement was accelerated by dry soil conditions leading to cracking and by a relatively dense argillic horizon below 20 $\mathrm{cm}$. This soil contains a mixture of $2: 1$ and $1: 1$ clays. The combination of the cracks and the relatively impervious layer resulted in a large amount of water moving downslope beneath the soil surface. The importance of soil cracks as avenues of water movement was very pronounced. During wet periods cracks disappear, reducing the extent of lateral water movement. For example, after the experimental plot and surrounding areas were wetted by rains, surface cracking was not noticeable. Twelve auger holes were dug around the plot in an attempt to follow lateral water movement. None of importance was detected. Given dry soil conditions in the Humatas soil and a sudden rainfall of $50 \mathrm{~mm}$, it is unlikely that appreciable lateral water movement would occur.

Cracking was evident under dry conditions in the Torres soil, also. However, this soil did not have a pronounced argillic horizon. Thus the lateral water movement which occurred was at deeper depths than in the Humatas.

In the Catalina soil, there was less lateral water movement than in the Humatas or Torres soils. None was observed in the Bayamón soil (sandy Oxisol).

Lateral water movement can be of importance in that the water carries with it fertilizer salts, primarily nitrates. If fertilizer trials are conducted where lateral water movement can occur in the root zone, there would be a possibility for mixing of treatments depending on soil water status, slope, and upon rainfall intensity or extent of irrigations.

In addition, scientists concerned with pollution often look at deep leaching of salts. Perhaps under certain conditions lateral water movement (and salt movement) should be monitored. This might aid in accounting for total salt balances within a given system.

\section{SOIL WATER TENSION VERSUS TIME RELATIONSHIPS}

Soil water tensions were generally obtained from the average of two tensiometers at each depth. Tension data have been corrected for depth and for negative wetting of mercury in the spaghetti tubing. 
Figure 3 shows typical tension-time relationships for an uncovered plot on the Humatas soil. Water movement was downward between all depths from 30 to $120 \mathrm{~cm}$ in response to tension differences. Upward water movement from the $30-$ to the $7.5-\mathrm{cm}$ zone occurred after $11 \mathrm{hr}$. This upward tension gradient was caused by water evaporation from the soil surface.

Figure 4 shows typical tension-time relationships for extended times on the Bayamón soil which was covered to prevent evaporation. Tensions normally increase slowly with time, evidence of continued slow drain-

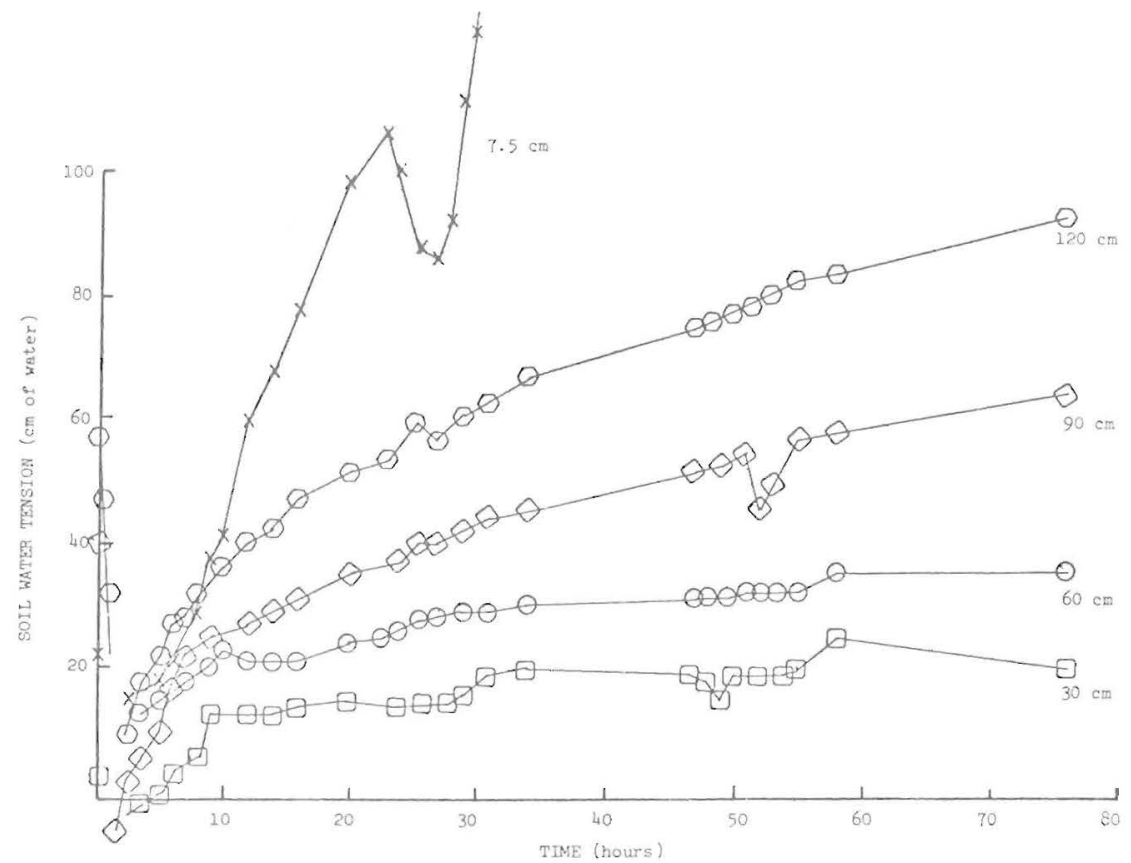

FIG. 3.-Soil water tension versus time in Humatas clay at five depths.

age. It is evident from figure 4 that drainage still occurred 6 days after an irrigation. The magnitude of the water loss from the profile, summed over a long period, is apt to be sizeable.

In spite of wide textural differences, patterns are similar on each soil. After irrigation, soil water tension near the soil surface dropped rapidly and became negative, thereby reflecting super-saturated conditions or water ponded on the plot. Generally, as drainage began at the upper depths, the wetting front reached the 90 - and 120-cm depths. Drainage began at all depths 2 to $3 \mathrm{hr}$ after the irrigation. Soil water tensions continued to increase with time, which was evidence of continued 
drainage. After 3 days of drainage and no evaporation, soil water tensions reached 20 to $80 \mathrm{~cm}$ of water (roughly 1/50 to 1/20 bar). Field capacicy was, therefore, considered to be 1/15 bar for the sandy Bayamón and 1/20 bar for the clayey soils.

\section{SOIL WATER MOVEMENT}

Experiments on clayey Oxisols and Ultisols showed that water movement at saturation was extremely high as evidenced by infiltration rates (fig. 1 and 2). In other words, hydraulic conductivity at saturation was very high. After 2 days, drainage slowed considerably: at 1/20 bar in

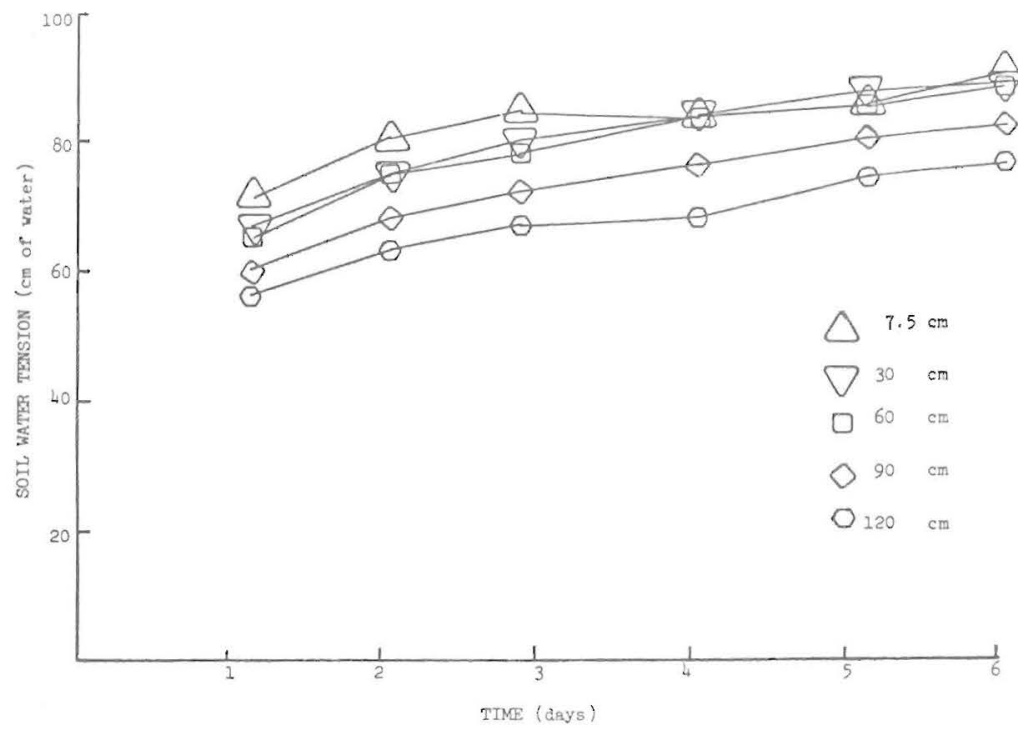

FIG. 4.-Soil water tension versus time in Bayamón loamy sand at five depths.

the clayey soils and $1 / 15$ bar in the sandy soil. Since water movement at those tensions was so slow, it appears that the capillary conductivity had decreased tremendously over a narrow range of tensions. This means that major water conducting avenues had dewatered.

The fact that water redistribution was initially very rapid and shortly thereafter very slow, implies that there may be two types of water conducting avenues. A third type might be cracks in 2:1 clays as exhibited by the Humatas soil. The two types of avenues might be labeled capillary pores (micropores between soil particles) and non-capillary pores (macropores between soil aggregates). This has been postulated by Sharma and Uehara (6). It might then be hypothesized that the major amount of soil water movement in the wet range occurs between the surfaces of 
structurally stable aggregates (non-capillary pores). Strong structural stability would be required to explain this type of water movement. In 2:1 clays, lattice expansion would destroy the macrostructure.

After non-capillary pores have dewatered, there is little further redistribution even though within the individual aggregates the pores may be saturated. Water contents at this time may reach $50 \%$ by volume. The fact that individual aggregates can remain saturated while not rapidly losing moisture may be explained by the fact that the non-capillary pores have dewatered and, therefore, present a barrier to further redistribution of liquid water.

The analogy between water movement in this system and a sand is clear. It would appear that clayey Oxisols simulate sands in flow characteristics and in release characteristics. With regard to water movement and release in Oxisols, it may be misleading to put emphasis on texture. Perhaps structural stability, type of structure, and type of clay are more useful parameters.

Due to the effect of structure on water movement in these soils, all water release data in the wet range were obtained on undisturbed samples. At low tensions, destroying the aggregates to run a sample would have the effect of creating greater soil water storage than would occur in the field.

\section{RESUMEN}

Se realizaron experimentos para determinar la capacidad de suministro de agua de dos Ultisols arcillosos, un Oxisol arcilloso y un Oxisol arenoso. En parcelas de $3 \mathrm{~m} .^{2}$ se instalaron tensiómetros hasta $120 \mathrm{~cm}$. de profundidad. Se inundaron y se cubrieron con plástico para evitar la evaporación. Se observó el movimiento del agua por infiltración y desagüe por 35 días utilizando los tensiómetros.

Para caracterizar el suelo en las parcelas que se regaron, se cavaron dos trincheras hasta de $150 \mathrm{~cm}$. de profundidad adyacentes a ellas. Se tomaron muestras de suelos a intervalos de $15 \mathrm{~cm}$. También se tomaron dos columnas de suelo de $30 \mathrm{~cm}$., en su estado natural, de 30 a $120 \mathrm{~cm}$. de profundidad.

La infiltración de agua fue rápida en todos los suelos. La infiltración típica alcanzó a $9 \mathrm{~cm}$./hora después de una hora de inundación continua. La gran estabilidad de las unidades estructurales de los suelos arcillosos permitió velocidades de infiltración mayores que en el suelo arenoso. La velocidad y la magnitud de la infiltración estaban inversamente relacionadas con el contenido inicial de agua en el suelo.

En los suelos arcillosos, el movimiento lateral de agua contribuyó significativamente a la alta velocidad de infiltración. Por ejemplo, en el suelo Torres, se observó un flujo de agua de una rajadura a una profundidad de $105 \mathrm{~cm}$. En el suelo Humatas, el movimiento lateral fue igualmente rápido, pero ocurrió a $20 \mathrm{~cm}$. de profundidad. Se atribuye este movimiento en el suelo Humatas a dos factores: a) movimiento en rajaduras grandes y b) movimiento en el punto de contacto entre terreno cultivado y no cultivado. Esto se acentuó por la acumulación de arcilla bajo la profundidad a que se aró el terreno.

La tensión a que se retiene el agua dos o tres días después de haber escurrido libremente el exceso no excede de 20 a $80 \mathrm{~cm}$. de agua (aproximadamente de $1 / 50$ a $1 / 12$ bar). Se es- 
tableció que la capacidad de campo occurre a $1 / 15$ bar en el suelo arenoso y a 1/20 bar en los arcillosos.

Se mencionan dos posibilidades para explicar el movimiento del agua: poros capilares (entre las partículas de suelo) y poros no capilares (entre los agregados del suelo). A causa del movimiento del agua por los poros no capilares, las características de la fluencia de los suelos arcillosos son similares a la del suelo arenoso. En cuanto a las características de suministro de agua, los suelos arcillosos y el arenoso fueron similares.

\section{LITERATURE CITED}

1. Lugo-López, M. A., Moisture relationships of Puerto Rican soils, Tech. Pap. 9, Univ. P.R., Agr. Exp. Sta., 97 pp., 1953.

2. Millar, A. A., and Gardner, W. R., Effect of the soil and plant water potentials on the dry matter production of snap beans, Agron. J. 64: 559-62, 1972.

3. Nielsen, D. R., Davidson, J. M., Biggar, J. W., and Miller, R. J., Water movement through Panoche clay loam soil, Hilgardia 35 (17): 491-506, 1964.

4. Rhoads, F. M., and Stanley, R. L., Jr., Response of three corn hybrids to low levels of soil moisture tension in the plow layer, Agron. J. 65: 315-18, 1973.

5. Richards, L. A., Soil moisture tensiometer materials and construction, Soil Sci. 53: $241-8,1942$.

6. Sharma, M. L., and Uehara, G., Influence of soil structure on water relations in low Humic Latosols: I. Water retention, Soil Sci. Soc. Amer. Proc. 32: 765-70, 1968.

7. Taylor, S. A., Use of mean soil moisture tension to evaluate the effect of soil moisture on crop yields, Soil Sci. 74: 217-26, 1952.

8. Wolf, J. M., Movement of chloride, nitrate and 1,2-dibromo-3-chloropropane in Panoche clay loam, Unpublished M.S. Thesis, Univ. Calif. at Davis, 1967. 